By EARLE RUGG

\title{
A Library Centered Program of Teacher Education
}

Earle Rugg is director of the Department of Curriculum and Libraries, Colorado State College of Education, Greeley.

$\mathrm{M}$ $Y$ ACCEPTANCE of the administration of our college library in 1933 came mainly from ten years of study of teacher education both as a professor of teacher education in Colorado State College of Education since 1923 and as a result of three years (1930-1933) of intensive study of teacher education as a specialist in curriculum research for the National Survey of the Education of Teachers. ${ }^{1}$ My studies and associations in the field of teacher education have convinced me that the center of college curricula and teaching should be the library, but I have found this as a reality in few teacher-preparing institutions.

In far too many teacher-preparing institutions-which include not only teachers' colleges and normal schools but even small arts colleges and junior collegesthe library facilities are decidedly inadequate. The library building, or in too many institutions the library room in another building, is very inferior to equivalent college facilities and equipment for other phases of college education. The library compared to instructional depart-

1 See Rugg, Earle, and others. Teacher Education Curricula. Vol. 3, National Survey of the Education of Teachers, United States Office of Education. Bulletin 1933 , No. 10, 1935 . ments is undermanned; members of its staff do not compare in rank, salary, or prestige with members of teaching departments. Furthermore, with a few notable exceptions such as Stephens College at Columbia, Missouri, there is rarely any conscious attempt to correlate course and library activity, notwithstanding the fact that the great majority of courses designed to prepare teachers are largely based upon and assume various mature reading, study, and research abilities. This lack of integration between curricula, instruction, and library activity is one of the "grand canyons" of teacher education. On the other hand it is a great challenge.

Our objectives $^{2}$ at Colorado State College of Education since 1933 have been centered on this problem of articulating college study of students in courses and curricula with the library. We shall here restrict this discussion to one of library policies and trends aimed to improve the teacher-education program at Colorado State College of Education. ${ }^{3}$

Space does not permit me to describe our general teacher-education program in detail. A few broad statements will have to suffice. The institution is organized

2 See Rugg, Earle, "Coordination and Integration of the Library and Instruction in College." A.L.A.

Bulletin 29:687-93, Sept. 1935 .
3 For details of our program in relation to the ${ }^{3}$ For details of our program in relation to the
"Tommission on Teacher Education, see Rugg, Earle. "Teacher Education Trends and Problems of Teacher Education at Colorado State College of Education."
Yearbook, American Association of Teachers Colleges 19:104-10, 1940. 
into two colleges, a general college, comprising the freshman and sophomore years, and a professional college, comprising junior and senior years and the graduate school. The emphasis in the first is upon orientation survey courses in the various major fields of knowledge to promote the general culture of prospective teachers. The emphasis in the professional college is upon the technical knowledge and skills attendant to the specialized teaching fields. Selection for teaching takes place at the end of the sophomore year and a variety of criteria are used during the freshman and sophomore years in determining those who are admitted into the technical phases of the pre-service education. One should add that our summer program is distinctly different. Whereas our personnel during the regular school year is overwhelmingly a typical group of pre-service, undergraduate, prospective teachers, our summer personnel consists preponderantly of mature, experienced teachers and administrators, most of whom are candidates for graduate degrees.

We at Greeley do not pretend that we have all of the answers. The tradition of fifty years (for this is the golden anniversary of the college) has been one of forward-looking, critical inquiry and experimentation. The main outcome that we hope for from this cooperative study of teacher education is aid in solving teacher-education problems still confronting us. One group of these problems involves library experimentation.

\section{A Functional Library Building}

Prerequisite to much of this experimentation are certain assets in our college library. First, we now have what we regard as the most unique library structure in America. In itself the building is ex- perimental. I quote from a forthcoming brochure advertising the dedication of the new library building to be held at Greeley, June 28 , in connection with a conference on school library problems:

Building planned cooperatively by administration, college architect and the library staff

Building organized in terms of accessibility of library materials to all students-the open stack principle

Unique features of building: modern architecture glass brick in all reading rooms two outside walls of stacks all glass stack rooms and stacks light color of paint building air cooled

stacks-steel floors, with stacks suspended from ceilings of decks mezzanine reading rooms reading room adjacent to stacks stacks easily convertible-reading rooms into stacks and vice versa

classroom with tables for instruction with library materials

modern furniture, silver gray, designed for the building by the college staff

Thus, we have the first essential of a library centered program-a functional building, designed to promote integration of college study in the classroom and in the library. We do not reflect, we believe, the plight of the librarian described by Branscomb" who said, "I have gotten a new building. ... Now what do I do next?" We propose to experiment in various ways to avoid Branscomb's warning: "So far as a library itself is concerned a program conceived in terms of facilities rather than more fundamental ends is all too likely to become enthralled to its own processes and resources." The building is a means, not an end. In our judgment the end is the better education

4 Branscomb. Harvie. Teaching with Books: $A$ Study of College Libraries. Association of American Colleges and the A.L.A., 1940, pp. 198-199. 
of the student-in our case a teacher in preparation for service.

\section{Conjunction of Library and Teaching Staff}

Our second asset is staff. Gradually over a period of several years a small but broadly-trained library staff has been recruited. All of our staff members now have library certificates from approved library schools, and all have master's degrees with the exception of one who will receive it this year. It has been our deliberate policy to use our own graduate school to develop our young staff members. Most of them have taken their graduate training in education and psychology because of the conviction that once located in a teachers' college a librarian must know the technical aspects of the teacher-education program and also because those courses in philosophy, psychology, guidance, curriculum, reading, and research are given in our division of education. Each library staff member has had opportunity to devote nearly half of the graduate work for his master's degree to individual educational research dealing with educational or psychological phases of library problems.

It is evident that our program for the guidance of students' reading cannot be undertaken alone by a staff with even this extended preparation. Our present staff is small, and, in terms of the tremendously increased load placed on the library since I933, can only meet the general technical and routine library activities and problems. Thus, additions to the counseling and guidance staff, as far as library activity is concerned, should not be made by appointing technically trained librarians. Rather we feel that we should capitalize upon the scholarship and tech- nical background of subject matter of our teaching staff by bringing them into close relationship with the students and library staff in the library. By that approach we believe that we can bridge the gap between course work and library activity and cause all concerned to see the needed synthesis of instruction that depends upon better educational utilization of the library resources of the college.

Hence we are planning to experiment with a broadened counseling program in the field of reading, study, and research in the new library. We now have one instructor prepared both in science and in education who is spending half of his time this spring in the library, working on curriculum and instructional problems. $\mathrm{He}$ is constantly counseling with students in the library and will continue to do so.

\section{The Library in the Teaching Program}

Next year we plan further extensions of this type of activity. Most of the general survey courses in science, social science, and world literature are now being taught in classrooms in the library that are adjacent to the stacks. Furthermore, the arrangement of the building with convertible bookstacks makes it possible to take a class into the stacks where the book resources for a given course are located. Next year, besides the reading counselor who gives about half-time to students in education and science, two other instructors will perform a similar combination of teaching and library-counseling activity in the survey courses in social science and world literature. Thus a small core of instructors is being developed who are intimately associated with the instruction and curriculum program and who will gradually become liaison officers between teaching divisions and the library. 
These instructors are all well prepared to guide the reading of students and to aid in adaptations of the reading program in these courses to the individual differences of students. Recall that the building provides offices and small seminar rooms where instructors may meet students individually and in small groups for this type of counseling. Of course much of this activity will take place in the stacks.

Furthermore, other professors whose main teaching resource is library material are meeting their students several hours a week in the library. The main criterion for teaching and consultation assignments in the library building is that a given course is dependent upon daily contacts with library resources.

Likewise we plan to provide selected library staff members with membership in the various teaching divisions. Since 1933 each member of the library staff holds the rank of instructor in the faculty, and, as fast as advanced preparation of the library staff member warrants, he will be promoted to a higher rank. The assistant to the librarian is well trained in the field of English-in fact is teaching the survey course in world literature in the summer. As this plan develops he will increasingly meet with members of the division of literature and language. Our director of acquisitions has his master's degree in political science. We plan that his instructorship will be in the division of social studies. Thus there is a reciprocal set of influences being set up to promote coordinations between the teaching and library staffs.

Yet the ultimate end of our program is self-education of each student. The building is now organized to aid him. The collection is easily accessible to him. The instructional and library staffs are being organized to guide and counsel him as to his reading study and research needs and aptitudes.

\section{Student Guidance in Library Usage}

For some years we have carried on a vigorous campaign to teach students who reveal deficiencies in accepted library usage. A library-usage test is given every freshman during freshman week. Our main conclusion after seven years' experimentation is that such activity is too general and can necessarily be but a beginning. Only through continuous guidance, along lines we have sketched above, will students develop the various library skills needed for their subsequent professional preparation.

We are also concerned with the voluntary reading of the students, both professional and cultural. Various methods of stimulation are being attempted such as less emphasis on textbooks and reserve reading and more on wide, extensive reading; an elective course in free reading; constant display of readable books, and the like. The next change still demanded, we feel, is a more flexible curriculum in which a greater adaptation can be provided for each student, in terms of data available as to his needs and abilities. That is our main curriculum problem and I believe that it can be solved in the near future.

Moreover, a library in a teacher-preparing institution has a unique function. Much of the activity of prospective teachers is important not alone for the contribution it must make to the better personal education of the student but for concomitant professional values. For example, each prospective teacher should participate in extra-curricular activities in college not alone for what participation 
will contribute to his own educational growth but also because he has to have this type of preparation as a part of his job in the field. This generalization is also true of library activity. Our beginning teachers at Greeley are potential leaders in communities when they start teaching. In general, graduates of teacherpreparing institutions start teaching in rural and small village schools where library resources are very limited. In my opinion possible improvments in library resources in such regions are largely dependent upon evangelical efforts of teachers who have experienced a vital library program in their pre-service period of preparation. ${ }^{5}$ Many teachers will perforce have to do what will be done to promote library resources in a community and to utilize and integrate library activity and instruction in their schools. Thus the ultimate criterion for evaluating our teacher-education program of library activity is the extent to which our graduates improve and use library resources in the communities where they teach.

\section{Technical Training for Public School Librarians}

One final comment, Colorado State College of Education does not offer a curriculum for school librarians. Our studies of teacher education proved that teachers' colleges have neither the staffs nor the resources to do specialized types of professional training. Rather, we have a cooperative curriculum with the School of Librarianship of the University of Denver. Our undergraduates who wish to major in the field of school librarianship complete

\footnotetext{
- So important is this thesis that I have tried to document it in detail in two sources. See my articles: "Janitors of Books or Reading Specialists." The Clearing House, 2:164-69 Nov. 1930; and "Librarian . Key Teacher." The Phi Delta Kappan, 22:311-20. Feb. 1940.
}

their first three years of college study at Colorado State College of Education. They follow a general secondary pattern of preparation including the basic courses in education, psychology, observation, and student teaching. (These are required by state law.) In our placement territory, school librarians are frequently called upon to teach. Hence each library major completes at least a minimum amount (twenty-four quarter hours) of subject matter in each of two teaching subjects. Qualified individuals who also meet conditions of admission to library school then complete their major in library science during their senior year at the School of Librarianship at the University of Denver. They thus may receive a library certificate from that library school and a bachelor's degree and teaching certificate from Colorado State College of Education. We also take one or two graduates of approved library schools as graduate library interns, who thus get experience in our college library and complete work for the master's degree in education. We believe that this is the best way to train teacher-librarians. We also believe that our fundamental task is to make every prospective teacher library-minded. ${ }^{6}$

This paper in a summary, condensed fashion illustrates activities, policies, and trends in the library area at Colorado State College of Education. It is evident, we trust, that our primary concern is to make the library function as the center of a program of teacher education. The organization, staff, and facilities now permit a much more vigorous promotion of properly teaching printed materials. I should add that our college conceives the

6 I have described our cooperative curriculum in considerable detail in "Shall the Teachers Colleges Prepare Librarians for Public School Libraries?" (Negative) in Yearbook, American Association of Teachers Colleges, 19:104-10, 1940. 
library as a center for many related educational activities. Our new department of audio-visual service is housed in the library, and the building offers great opportunity for exhibitions of arts and museum materials. We have the active support and cooperation of the administration, faculty, and students. The challenge of teacher education under such conditions can and will, I believe, be met.

\section{Commission on Teacher Education Extends Activities}

The Commission on Teacher Education of the American Council on Education is extending its activities to include the preand in-service preparation of college teachers. Director Karl W. Bigelow has selected Dr. Ernest V. Hollis of the College of the City of New York to direct the undertaking.

Since 1939 the commission has been cooperating with 34 colleges and school systems and with three state-wide programs in their efforts to improve the pre- and inservice preparation of elementary and secondary school teachers. Through a staff of ten persons it has sought to provide consultant and other services to these indigenous efforts for improving the quality of teachers and teaching. In addition to the Washington staff the commission maintains a collaboration center at the University of Chicago for the study of child development and teacher personnel. The demonstrations are scheduled for a fiveyear period, about half of which has elapsed. Subject to review, the General Education Board has earmarked for the entire project a series of grants which approximate $\$ 900,000$.

During the fall semester Dr. Hollis expects to visit graduate schools whose
Ph.D.'s predominately go into college teaching and undergraduate colleges that are actively promoting the in-service growth of teachers. He invites interested college professors and administrative officers to write him (744 Jackson Place, Washington, D.C.) of their programs and plans and to indicate how he may be of service. It is not the commission's plan to conduct intensive research but rather to act as a clearing house and stimulative agent for indigenous programs already underway. It clearly recognizes that the preparation of college teachers is a university-wide function.

Dr. Hollis has a rich background for leadership in the preparation of college teachers. His B.S. and M.S. degrees were in botany and plant pathology, followed by a year's graduate work in history and sociology. His Ph.D. degree specialization was in the problems of higher education. $\mathrm{He}$ is a regular contributor to professional magazines and is author of the professionally important book, Philanthropic Foundations and Higher Education. His experience has ranged from country school teacher through the several professional ranks to a department headship and a college presidency. 